\title{
Research, friendship, the joy of writing and the editorship of Journal of Nephrology
}

\author{
Giovanni Gambaro ${ }^{1}$ Giorgina Barbara Piccoli ${ }^{2,3}$
}

Published online: 1 July 2020

(C) Italian Society of Nephrology 2020

"Giovanni, we should write an editorial about passing the baton at JN".

"Farwell editorials are so damn boring," was the answer. "And presentation editorials are usually pretty pretentious..."

Being the incoming editor of Journal of Nephrology, JN to its friends, is like directing Le Nozze di Figaro after Carlo Maria Giulini. It is practically impossible to do better. There is no point asking a shy man to comment on his achievements, and no point presenting a list of high-sounding proposals.

$\mathrm{JN}$ is the international journal of the Italian Society of Nephrology, an association that like all similar societies has seen friendships and fights, alliances and gossip. No scientific society is perfect. We hope, however, to continue the tradition of JN as a journal that can take advantage of Italian curiosity and elegance, our slightly anarchic dynamism, to involve new authors and learn from the international community. JN is alive and on the move; many changes are underway, many will follow (Table 1).

Working with Giovanni in recent months has allowed me to reflect on the joy of science, and on the importance of friendship in our profession; we therefore decided to exchange our thoughts on these topics, involving our editors and, we hope, highlighting the common line we are following to make Journal of Nephrology a journal that conveys

Members of the Editorial Board of Journal of Nephrology: Carlo Basile, Antonio Bellasi, Vincenzo Bellizzi, Paolo Cravedi, Rosanna Coppo, Sandro Mazzaferro, Umberto Maggiore, Andrea Onetti Muda.

Giorgina Barbara Piccoli

gbpiccoli@yahoo.it

1 Nephrology Department of Medicine, University of Verona, Verona, Italy

2 Néphrologie, Centre Hospitalier Le Mans, Avenue Roubillard 196, 72000 Le Mans, France

3 University of Torino, Torino, Italy good science and shares outstanding papers, while remaining open to new ideas and new voices, a journal in which the Italian tradition is an added value, and in no way a means of discriminating against researchers in other countries.

Giovanni, what is the role of research in medicine?

It is obvious to say that it is important. I think it is the essence of medicine. When we think about research, we imagine laboratories, cohorts of patients, databases, teams of investigators, etc. Even though science is an essential part of practicing medicine, being a doctor involves much more than having scientific knowledge.

In my opinion, the general practitioner treating one single patient, in a small village in a remote valley can be a researcher, if this person applies scientific reasoning. The intensive-care doctor in the small hospital in Codogno in Lombardy who discovered "Patient 1" during the SARSCovid 19 pandemic, marking the official start of the epidemic in Italy, was engaging in lateral thinking, experimenting with a new hypothesis. In my opinion, this research has the same dignity as the research done in a laboratory or in investigating large cohorts.

Giovanni's views chime with those of our board. One comment stands out in his ironic declaration of his love of medicine: the role of research is essential for human survival (from an optimistic point of view) or for human extinction (from a pessimistic one). Personally, I like doing research, even my (modest) clinical research because it is an essential aspect of my love for my job; doing research helps my brain to continue to perform (as much possible with the residual neurons it has). Medicine without research would be destined to become a merely technical performance. Another editor underlined humility: medicine without research is an empty shell; everybody can be self-promoting and present expert opinions. Research is humbling and constructive. A third editor commented more broadly on the medical profession: my strong conviction about the difference between a bad/mediocre doctor and a good one is that the former does not have the gift 
Table 1 After achieving the goal of entering in the first quartile of impact factor, a series of changes mainly aimed at increasing interest and flexibility, are being undertaken

\begin{tabular}{|c|c|c|}
\hline Action & State of the art & Future developments \\
\hline \multirow[t]{2}{*}{$\begin{array}{l}\text { Internationalization of the } \\
\text { editorial board }\end{array}$} & International editors are being increasingly recruited & $\begin{array}{l}\text { The division into different subjects should also help } \\
\text { balance competences and allow us to recruit experts } \\
\text { with different specializations }\end{array}$ \\
\hline & $\begin{array}{l}\text { While the present EiC and associated editors are Ital- } \\
\text { ians, two of them work in different countries (USA } \\
\text { and France) } \\
\text { All continents are represented on the present editorial } \\
\text { board }\end{array}$ & $\begin{array}{l}\text { The board will continue to recruit editors regardless of } \\
\text { their age (room for the young, honor to the masters), } \\
\text { gender and national origin. Expertise and commit- } \\
\text { ment are the only requirements that counts }\end{array}$ \\
\hline Giving patients a voice & $\begin{array}{l}\text { Giving patients a voice is one of the novelties } \\
\text { introduced in recent months. The first editorial on } \\
\text { patients' perceptions of the lockdown and COVID } \\
\text { epidemics has been published }\end{array}$ & $\begin{array}{l}\text { We plan to systematically accompany the most relevant } \\
\text { papers, and those potentially changing the clinical } \\
\text { approach in a way that affects our daily practice with } \\
\text { editorials highlighting patients' views and perceptions }\end{array}$ \\
\hline Encouraging discussion & $\begin{array}{l}\text { The number of editorials is progressively increasing. } \\
\text { It is hoped that these short opinion-based interven- } \\
\text { tions will encourage discussion }\end{array}$ & $\begin{array}{l}\text { Commentaries and controversies may be proposed in } \\
\text { the future, to encourage reflection on chosen topics }\end{array}$ \\
\hline Giving space to clinical cases & $\begin{array}{l}\text { Three new sections have been added: nephrology } \\
\text { images, nephrology quizzes (zebra puzzles) and } \\
\text { lessons for the clinical nephrologist. The first papers } \\
\text { accepted are available on line }\end{array}$ & $\begin{array}{l}\text { Updating of the site has started and new instructions for } \\
\text { authors will be posted } \\
\text { Options for blogs or media answers are being evaluated }\end{array}$ \\
\hline Increasing media visibility & $\begin{array}{l}\text { The first visual abstract is presently on line } \\
\text { A team of young editors has been recruited to improve } \\
\text { media sharing. A Twitter account has been created }\end{array}$ & $\begin{array}{l}\text { Improving sharing on media, enhancing dissemination } \\
\text { is not only a service to our authors, but also a way to } \\
\text { increase the visibility of the journal and attract high- } \\
\text { quality studies }\end{array}$ \\
\hline Improving format quality & $\begin{array}{l}\text { Formal and language support is occasionally provided } \\
\text { by members of the editorial board } \\
\text { Adherence to internationally agreed formats is } \\
\text { increasingly being required }\end{array}$ & $\begin{array}{l}\text { Systematic language review of abstracts; identification } \\
\text { of high quality, affordable language editors, in line } \\
\text { with the offer of the most important international } \\
\text { nephrology journals }\end{array}$ \\
\hline $\begin{array}{l}\text { Periodically changing the } \\
\text { cover }\end{array}$ & $\begin{array}{l}\text { The JN cover can be tweeted and shared via social } \\
\text { media. Enhancing its variety is intended to make the } \\
\text { journal more attractive }\end{array}$ & $\begin{array}{l}\text { Potential images are being gathered from different } \\
\text { sources, and will be selected for our } 2021 \text { issues }\end{array}$ \\
\hline $\begin{array}{l}\text { Developing teaching experi- } \\
\text { ence }\end{array}$ & $\begin{array}{l}\text { JN editors have actively participated in meetings and } \\
\text { been present on informal occasions and elicited sub- } \\
\text { missions. Writing workshops were held in Mexico in } \\
\text { 2018-2019 }\end{array}$ & $\begin{array}{l}\text { Workshops on how to write case reports, case series, } \\
\text { and observational studies could be offered to young } \\
\text { colleagues and shared with emerging countries }\end{array}$ \\
\hline
\end{tabular}

of being curious. In other words, where the average person sees an end, the scientist perceives evolution. This is the essence of research in medicine. As Marcel Proust wrote: "The real voyage of discovery consists not in seeking new landscapes, but in having new eyes". To conclude, my oneiric vision is that research is a state of mind. Or, as another editor said, research is what makes the great scientific cocktail sexy.

Finally, one of the editors added, research is a neverending process that accompanies and enriches our scientific commitment. In fact, the etymology of the word research is to "search again".

Having praised the humble physician who thinks outside the box, icon of our profession, and consequently underlined the reasons why JN is by vocation a clinical research journal, which will give increasing space to lessons that a clinical nephrologist can learn from a single unusual case or a fascinating image, we discussed why we write papers (and actually enjoy doing this).

Writing a paper is like making a good wine. You have gathered grapes/data and they could potentially be very good. However, you now have to develop their flavour and this requires reflection, patience, knowledge, experience. The same process is similar to describing and discussing research results.

When you have submitted a paper, something like a chess game starts, involving you and reviewers. To deliver the full potential of your results, you need to imagine different scenarios and alternative ways of explaining them, you need to produce the most convincing explanation possible.

Descriptions of this enjoyable yet demanding intellectual game recur in the words of the editors. One of them described himself as a lazy person with an active imagination who has always enjoyed writing and drawing. 
Another editor underlined the importance of doubt: I do not really know why I like writing papers. It requires making an effort, being systematic, when one has other apparently more important things to do. Meeting deadlines is time consuming. When I have finished it always seems that something has been left out or is wrong. I almost never re-read my old papers. However, writing gives me the opportunity to verify my thoughts. Also, it seems to me that with my work I have planted some seeds, I have left a sign of my presence in the scientific community.

In this optimistic, slightly metaphysical outlook, one question remains unanswered: why are we all willing to spend our evenings writing or commenting on a paper submitted to JN instead of drinking a glass of wine with friends, looking at the stars with a telescope, or even watching a relaxing, maybe even stupid TV fiction?

One of the editors answered: this is the exact same question I was asking myself. However, as a matter of fact, I am drinking a glass of wine while I am writing to you.

Another editor was more serious: in the realm of important things, writing is an active challenge. You are responsible for every word you write and wording your ideas or thoughts is among the most difficult things for human beings to do. So, it is an exciting moment in life, different from relaxing activities. Both are necessary. The challenge is to strike the right balance between the two.

The Roman poet Marcus Valerius Martialis wrote: "Non est vivere sed valere vita est" (Life is not being alive but being well), now the motto of the Royal Society of Medicine in London. Doing clinical research and then writing a paper gives me the deep sensation of "valere", of being well.

Wine is a good example, as in Italy drinking a glass of wine together is a sign of friendship. One of the authors described why he doesn't mind staying up late as follows: usually, because there is something exciting to write, otherwise I would definitely prefer a nice glass (or two) of wine with friends. He added: friendship dissolves distrust and unhealthy competition, makes it possible for fruitful thoughts to merge, turns what would otherwise be stressful in everyday work into something pleasant, makes it fun. However, my favourite answer (I'm obviously biased) is the following: I'm here writing now because of friendship, Giorgina, since you are soon going to be my editor.

This answer leads us once more to the next question, on the role of friendship, a value and a component of every society, including scientific ones.

In this regard, Giovanni Gambaro told us a bit of his story. Our job is a difficult one, he wrote. We have to take decisions every day, decisions that may have a strong impact on a patient's health. In those moments, most of the time we are alone. We may also work in highly competitive settings. Our job is frequently stressing. Having friends among colleagues means having the chance to discuss our decisions without any reservations, to be supported and encouraged in our loneliness, to take our everyday working life more lightly. I have recently experienced the importance of friendship in medicine. After many years I returned to the Verona Hospital where I found two colleagues I had worked with in the past, two friends. Being in a new hospital, with higher responsibility is a great challenge. However, having two friends who I can rely on is a great relief.

I cannot disagree with him. When I moved to France, the beginning was tough. The group was small, the system was different, we had to combat deeply rooted prejudices against our service. Three friends came to the rescue, and sent us some bright residents who were crucial not only for helping with daily work, but also for sharing a wealth of interesting data, and in the publishing of our first "made in France" papers. We shared meals and dreams. These residents, now young nephrologists, are scattered throughout Italy. I have been to their thesis and weddings, and the chain of friendship is now a few links longer.

I am sure all the editors agree on the central role of friendship. One of them observed that friendship has such a central role in keeping us alive that it is natural that it plays a central role in medicine as well. As a character in an Ermanno Olmi film says, "All the books in the world are not worth a coffee with a friend," a quote that I keep on my desk.

Another editor found it a much more difficult question, and answered critically. Friendship in medicine happens, but rarely, and it has high hurdles (first of all competition) to overcome. A common sense of belonging and of having similar interests and feelings is the glue. That may abruptly fail to work in case of competition. However, it remains true that "whoever finds a friend, finds a treasure".

According to Giovanni, his experience at JN had a bright side: interacting with authors, editors and reviewers, and with the publisher, having a ringside-seat view on what is going on in research. It was all interesting and was enough to make him love this job. I must admit, however, that what is most rewarding for me is working to obtain results. I was previously editor-in-chief of Giornale Italiano di Nefrologia, the educational journal of the Italian Society of Nephrology. Editing Giornale Italiano di Nefrologia was just playing, having fun; editing JN was a responsibility. The Italian society was torn about whether to abandon JN or investing energy and money in a journal which could try to share the high international reputation of the Italian research in nephrology. Thus, this was a very strong challenge for me, and what I loved was the learning curve as a "successful" editor- in- chief.

Not everything that glitters is gold, however. Our editorin-chief knows it, and candidly describes that "the emperor has no clothes". I was committed to improving the international position of JN. However, my colleagues, working as "private" investigators, didn't have the same commitment. 


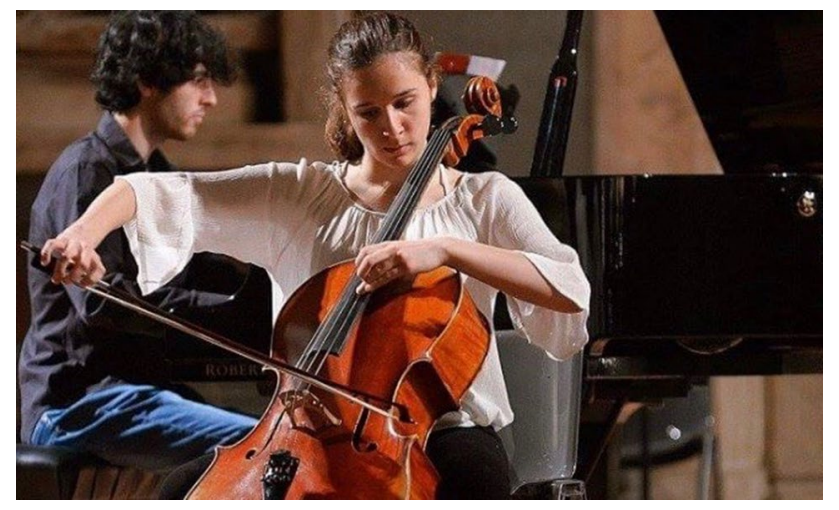

Fig. 1 A good editorial team may be seen as between a small chamber orchestra, and a well trained duo. For being good, it needs reciprocal appreciation, confidence, search for excellence and joy of playing together. (Courtesy of Clara Piccoli)

What was very frustrating was the submission of second/ third quality papers from some of those members, especially after they had been rejected by higher ranking journals (...)

Giovanni, do you agree that this is not a farewell?

We need your kind, firm decisions, your vast culture, and your detached regard. These years JN has been your creature, we'll try to take care of it, but not without you.

One of my nieces plays the cello; we look forward to her performances with joy and fear: life is not always kind to artists. When I recently asked her about her future plans, she answered she wasn't sure this was the best thing to do but could not imagine herself doing anything but music (Fig. 1).

I fear and hope that for many of us medicine is the same.

As a new editor I hope that JN can help give a voice to passionate physicians, physicians from all over the world, as it did with Giovanni Gambaro as editor, and we all hope to do it not only with his help, but also with his friendship.

Funding None.

\section{Compliance with ethical standards}

Conflict of interest The author declares that they have no competing interest.

Ethical consent None required.

Publisher's Note Springer Nature remains neutral with regard to jurisdictional claims in published maps and institutional affiliations. 